УДК 330.341.2

DOI: 10.35340/2308-104X.2021.90-1-01

\section{МЕТОДОЛОГІЧНІ ПІДХОДИ ДО ВИЗНАЧЕННЯ КРИТЕРІЇВ ЕФЕКТИВНОСТІ ІНСТИТУЦІЙ}

\author{
METHODOLOGICAL \\ APPROACHES TO DETERMINING \\ THE CRITERIA FOR THE \\ EFFECTIVENESS OF INSTITUTIONS
}

\author{
TAPACEHKO O. B., \\ кандидат економічних наук, \\ ст. викладач кафедри управління \\ персоналом та економіки \\ підприємства, \\ КУМАЧОВА А. С., \\ кандидат наук з державного \\ управління, доцент кафедри \\ управління персоналом та \\ економіки підприємства, \\ Донецький державний університет \\ управління
}

\author{
TARASENKO O., \\ $\mathrm{PhD}$ in Economics, Senior Lecturer \\ of the Department of HR \\ Management and Business \\ Economics, \\ KUMACHOVA A., \\ PhD in Public Administration, \\ Associate Professor of the \\ Department of HR Management \\ and Business Economics, Donetsk \\ State University of Management
}

У статті досліджуються підходи до визначення критеріїв ефективності інститутів. Аналізуються підходи неокласичної теорії, неоінституціоналізму, теорії організації, поведінкової економіки до визначення ефективності. У статті показано, що внаслідок того, що інститути є результатом дії стихійних конкурентних сил і усвідомленої діяльності економічних агентів щодо підвищення якості кооперації, можна формулювати критерії ефективності інститутів. Відзначається суттєвий недолік існуючих підходів до оцінки ефективності інститутів, який полягає в ігноруванні при аналізі нерівномірності розподілу переговорного потенціалу між економічними агентами. Доведено, що у разі невідповідності розподілу вигод від створення інституту існуючого розподілу переговорної сили, більш сильна сторона мотивована створювати неформальні інститути, які, скорочуючи індивідуальні трансакційні витрати, збільшують громадські.

Ключові слова: інституція, ефективність інституцій, переговорна сила, інституціональний дизайн.

В статье исследуются подходы $к$ определению критериев эффективности институтов. Анализируются подходы неоклассической теории, неоинституционализма, теории организации, поведенческой экономики к определению эффективности. В статье показано, что вследствие того, что институты являются результатом действия стихийных конкурентных сил и осознанной деятельности экономических агентов по повышению качества кооперации, можно формулировать критерии эффективности институтов. Отмечается существенный недостаток существующих подходов $к$ оценке эффективности институтов, который заключается в игнорировании при анализе неравномерности распределения переговорного потенциала между экономическими агентами. Доказано, что в случае несоответствия распределения выгод от создания института существующего распределения переговорной силы, более сильная сторона мотивирована создавать неформальные институты, которые, сокращая индивидуальные трансакционные издержки, увеличивают общественные.

Ключевые слова: организация, эффективность институтов, переговорная сила, институциональный дизайн.

The article deals with the approaches to determining the criteria for the effectiveness of institutions. The approaches of neoclassical theory, 
neo-institutionalism, organization theory, behavioral economics to the definition of efficiency are analyzed. The article shows that due to the fact that the institutions are the result of the action of spontaneous competitive forces and the conscious activity of economic agents in improving the quality of cooperation, it is possible to formulate criteria for the effectiveness of institutions. There is a significant lack of existing approaches to assessing the effectiveness of institutions, which consists in ignoring in analyzing the uneven distribution of bargaining power between economic agents. It is proved, that if the distribution of benefits from the establishment of the institution does not correspond to the existing distribution of negotiating power, the stronger side is motivated to create informal institutions that, by reducing individual transaction costs, increase the public costs.

Keywords: institute, efficiency of institutions, bargaining power, institutional design.

Постановка проблеми. На сучасному етапі розвитку економічної теорії $€$ досить популярним пояснення різної швидкості економічних реформ у постсоціалістичних країнах різною ефективністю інституцій. Однак концепція економічної ефективності інституцій є у найкращому випадку нечіткою.

Неокласична економічна теорія в якості критерію ефективності обирає результати, які виходять з базової неокласичної моделі. Ця модель передбачає наступні передумови [1, с. 44-45]:

повна інформація;

нульові трансакційні витрати;

чіткі права власності;

повна раціональність;

максимізуюча поведінка економічних агентів.

Ефективність, з точки зору неокласиків, полягає у тому, що ресурси використовуються ефективно, якщо вони знаходяться у користуванні того, для кого вони представляють найвищу цінність. При чому, остання визначається здатністю та готовністю сплатити за ресурс. Отже, незалежно від початкового способу розміщення ресурсів, шляхом укладання угод між власниками ресурсів 3 економічними агентами, які здатні здобувати найбільшу корисність 3 наданих ресурсів. Таким чином, будь-які результати економічної діяльності, які відхиляються від еталону, розглядаються як неефективні [2]. Інституції при цьому жодним чином не впливають на кінцевий результат розміщення ресурсів, тому залишаються поза межами аналізу. Однак такий підхід піддається критиці 3 боку прибічників інституціональної теорії.

Аналіз останніх досліджень та публікацій. Дослідженню проблеми ефективності інституцій приділяли увагу: Д. Норт, який на підставі порівняльного аналізу інституцій у європейських країнах дав поясненню різних траєкторій їхнього розвитку [1]; О. Вільямсон, який порівнював ефективність різних структур управління та інституцій, на яких вони ґрунтуються [3; 4]. Р. Коуз [5], А. Алчіан [6] та Х. Демсец [7] у своїх роботах викрили недоліки неокласичного критерію ефективності використання ресурсів. Серед українських дослідників вартими уваги $є$ роботи С. Архієрєєва та Я. Зінченка [8], які запропонували підхід до кількісної оцінки ефективності інституцій; та В. Дементьєва [9], який довів, що існуючі інституції відбивають владних потенціалів контрагентів.

Мета цієї статті полягає в обґрунтуванні методологічних підходів до визначення критерію інституціональної ефективності. 
Виклад основного матеріалу дослідження. Аналіз проблеми інституційної ефективності варто почати 3 питання Д. Норта «що створює ефективні інституції?» та подовжити це питання: а що власне $є$ ефективна інституція, у чому полягають критерії іï ефективності [1, с. 16].

Для відповіді на питання про принципову можливість формулювання критеріїв ефективності інституцій, важливим $є$ відповідь на питання про співвідношення елементів дизайну (свідомої діяльності з побудови інституцій) та еволюції (стихійних, об'єктивних чинників розвитку інституційної середи). Інакше, якщо припустити, що створення інституцій $€$ лише продуктом стихійних сил еволюції, питання про критерії інституційної ефективності стає безглуздим.

Можна виокремити чотири підходи щодо виникнення та розвитку інституцій.

По-перше, це підхід, який трактує інституції як відносини, які створюються свідомо. Цей підхід отримав назву інституційний дизайн. Е. Александр дав наступне визначення інституційному дизайну як «розробці та реалізації правил, процедур, організаційних структур, які покликані забезпечувати та обмежувати діяльність та поведінку для досягнення бажаних цілей або поставлених задач» [10, с. 1]. Таким чином, будь-які інституції $€$ результатом колективної дії економічних агентів.

В якості слабкого місця цього підходу Буйтелаар відмічає те, що залишається невизначеним, чому серед багатьох інституційних альтернатив обираються одні, а не інші, а також чому одні інституції здатні проіснувати десятки та сотні років, а інші не демонструють подібної здатності до виживання [11].

По-друге, протилежний наведеному вище підхід, який можна назвати еволюційним. Він передбачає, що певний початковий набір інституції еволюціонуе подібно світу природи через механізми мінливості та відбору для того, щоб спрощувати економічним агентам досягнення власних цілей. Подібний підхід до інституційних змін можна знайти у роботах представників економічної теорії трансакційних витрат Х. Демсеца та О. Вільямсона. Інституції еволюціонують з метою мінімізації трансакційних витрат, що за умови сталої технології підвищує економічну ефективність [3; 7].

Інституції ринку також змінюються і результатом $є$ спонтанне зменшення витрат організації множини індивідуальних трансакцій.

Однак критики цього підходу, наприклад Дж. Ходжсон, вказують на те, що не існує емпіричних доказів підвищення економічної ефективності через розвиток інституцій. Крім того, не отримує належного пояснення існування сталих інституцій, які підтримують неефективні господарські чи політичні практики [12].

Третій підхід асоціюється з ім'ям Д. Норта. Сутність його полягає у тому, що деякі інституції виникають шляхом свідомої діяльності економічних агентів (наприклад Конституції), інші виникають шляхом еволюції, але вибір інституцій у минулому відсікає частину можливостей формування інституційних конфігурацій.

Таким чином, інституційна зміна характеризується залежністю від траєкторії попереднього розвитку. Тобто роль інституційного дизайну зводиться лише до обґрунтування вибору однієї 3 небагатьох інституційних альтернатив.

Д. Норт наголошуе на тому, що головна роль інституцій у суспільстві - зменшувати невизначеність шляхом встановлення сталої 
структури взаємодії між людьми. А також що «...ефективні інституції прищеплюються в державі, якій притаманні стимули до створення та забезпечення прав власності...» [1, с. 179].

Але також Д. Норт пише: «...я відмовився від погляду на інституції через призму поняття ефективності». Правителі вигадали права власності задля власних інтересів, а трансакційні витрати виникли внаслідок панування неефективних прав власності» [1, с. 16].

Підвищення ефективності інституцій, таким чином, пов'язуються 3 ефектом навчання, сутність якого у тому, що чим далі іде розвиток інституцій, тим ефективнішими вони стають за рахунок накопичення інформації, розповсюдження загального знання.

Слабкий бік цього підходу полягає у ігноруванні асиметрії економічної влади. Дж. Ходжсон стверджує, що інституції будуть існувати незалежно від того, ефективні вони чи ні, якщо обслуговують інтереси коаліції економічних агентів, які мають владу [12].

3 точки зору соціологічного підходу інституції формуються та змінюються під впливом не скільки індивідуальної раціональності та особистих цілей, скільки групової раціональності та колективних цінностей. Інституції створюються у відповідності до певних суспільних стандартів. Формування та розвиток інституцій призводить до формування цінностей, які схвалюють та підтверджують функціонування інституцій і, таким чином, процес стає таким, що сам себе підсилює.

Відмінність цього підходу від наведених вище у тому, що визнається культурна цінність інституцій. Вони сполучають окремі цінності замість того, щоб лише обслуговувати потреби індивідів під час обміну або у процесі організації виробництва. Інституції забезпечують рамки, у яких скеровується поведінка. Ключовий момент інституційного розвитку $є$ процес інституціоналізації, який Б. Артс та П. Лерой визначають як процес у якому відбувається усталення нестабільної поведінки та формування певних структур відносин між індивідами, а потім ці структури визначають поведінку осіб [11]. Таким чином, процес інституціоналізації у теперішньому часі знаходиться під впливом попередньо сформованих інституційних структур. Отже, у процесі інституційного розвитку інституції одночасно перетворюються на предмет, який потрібно пояснити та на інструмент пояснення, що звичайно ускладнює аналіз.

3 цього витікає, що інституційний дизайн та інституційна еволюція не $€$ взаємовиключними альтернативами. Інституційний дизайн $є$ скоріше частиною механізму інституційної еволюції. Інституційний розвиток ініціюється особою чи групою осіб з метою «покращення» інституцій, яке 6 сприяло досягненню приватних вигод (здобуття тимчасової монополії, підвищення ефективності, розширення ресурсної бази, підвищення прозорості тощо). Але згодом, нові покращенні інституції розповсюджуються у мережі відносин між індивідами і стають загально прийнятними та загальновживаними.

Інституціоналісти, починаючи з Р. Коуза, вказують на те, що ринковий механізм не $є$ безкоштовним, тому щоразу права власності передаватимуться від менш ефективного власника до більш ефективної цінності (потенційна продуктивність) ресурсу зменшуватиметься і скоріш за все, через неповноту інформації, ресурс так ніколи не підпаде під контроль найбільш ефективного власника. Важливим для аналізу інституційної ефективності $€$ застосування теореми Коуза. 
Згідно з теоремою Коуза: «...якщо права власності чітко визначені і трансакційні витрати дорівнюють нулю, то алокація ресурсів (структура виробництва) залишатиметься незмінної незалежно від змін в розподілі прав власності, якщо відволіктися від ефекту доходу» [14, с. 343-344].

Фактично Р.Коуз формулює умови, за яких неокласична концепція оцінки ефективності інституцій стає релевантною. Виявляється, що їх не так вже й мало. По-перше, права власності повинні бути чітко визначені, тобто існуюча система інституцій забезпечує повну інформацію про існуючі права власності та надійний захист прав власності. По-друге, трансакційні витрати повинні дорівнювати нулю. У літературі $є$ тенденція ототожнювати ці дві умови, тобто стверджувати, що чітка специфікація прав власності автоматично призводить до нульових трансакційних витрат. Однак аналіз арифметичних прикладів, які наводить Р. Коуз у статті «Природа соціальних витрат», доповнений гіпотезою В. Дементьєва про зловмисний характер дій хазяїна ранчо (корови), тобто такий, що не може розглядатися як технологічна екстерналія, та навмисний характер пошкодження полів з зерном з метою змусити фермера піти на певні поступки (чи під час переговорів чи у грошовому еквіваленті) [9], доводить нетотожність цих умов.

3 одного боку, ці витрати не є таким, що забезпечують угоду, хоча взагалі то досить цікаво, що власне $є$ предметом угоди - фактично ми маємо справу з інституціонально неврегульованим випадком - тому існує певна невизначеність у кінцевому розподілі доходів та видатків. Якщо право на пошкодження посівів було чітко закріплено за ранчером, за інших зазначених умов утворилася 6 ситуація, коли ранчер міг би здійснювати пошкодження посівів у тих масштабах, які б забезпечували його власні потреби у зерні (якщо зважити на те, що його функція граничної корисності м'яса має спадний характер та покращення загальної корисності відбуватиметься за рахунок додавання до споживчого набору продукції фермера). Зворотна ситуація описана Р. Еліксоном, який вказує на те, що у графстві Шаста (Каліфорнія) домінуючим $€$ неформальна інституція, яка передбачає відповідальність за пошкодження посівів інших фермерів, попри те, що правова система передбачає ряд виключень, за яких відшкодування не передбачено [15, с. 97-100].

3 іншого боку, ці витрати формують (можуть формувати) переговорні позиції фермера та ранчера під час іншої угоди, яку можливо буде укладено у майбутньому, наприклад, під час переговорів з приводу продажу земельної ділянки третій стороні або одному 3 учасників. При чому хазяїн ранчо повинен витратити ресурси на додаткових корів, як засіб залякування.

Подібна ситуація отримала назву у теорії ігор «credible commitment» або достовірне зобов'язання [16]. Таким чином, у зазначених випадках за умови нульових трансакційних витрат та повних прав власності можливі варіанти дій, які $б$ призводили 6 до певних витрат. В. Дементьєв вказує на те, що ці витрати виходять за рамки традиційної дихотомії «трансакційні - трансформаційні» витрати і називає їх витратами трансформації поведінки і пов'язує її з проявом волі однієї людини стосовно іншої. При чому, відзначається соціальний характер цих витрат [9].

Однак соціальний характер мають і трансакційні витрати опортуністичної поведінки. Таким чином, ми стикаємось з ситуацією 
коли навіть відсутність трансакційних витрат за умов статичного аналізу перетворюється на джерело формування трансакційних витрат у майбутньому, якщо аналізувати динамічний аспект цієї проблеми.

А. Алчіан у своїй роботі «Невизначеність, еволюція, та економічна теорія» піддав критиці такий критерій ефективності, як «максимізація прибутку» за умов неповної інформації та непевних передбачень [6]. $\mathrm{Ha}$ захист твердження про те, що максимізація прибутку не може розглядатися як реальний фактор, що мотивує економічну діяльність Алчіян наводить доказ Г. Тінтнера. Приймаючи рішення за умов невизначеності, економічний агент обирає певну дію (лінію поведінки), якій властивий певний розподіл можливих економічних результатів, лише один 3 яких перетвориться на реальність. За цих умов відбувається вибір оптимального розподілу, а поняття «максимальний розподіл» у математиці просто відсутнє [6, с. 212].

За таких припущень А. Алчіян робить висновок про те, що вибір плану дій по виживанню в умовах невизначеності, в тому числі нечіткості та нестабільності інституціонального середовища, відбувається за схемою подібною до природного відбору. Економічні агенти, які змогли вижити позичають або копіюють ділові практики, які пов'язуються з економічними досягненнями найбільш успішних фірм, а ті з них, які виявилися недосконалими за позичальниками, в разі успіху стають інноваторами, а в разі провалу перетворюються на «...безвідповідальних порушників правил, що добре зарекомендували себе на практиці...» [6, с. 218].

За таких умов єдиним критерієм ефективності інституції стає економічне виживання економічних агентів. Такий критерій звичайно $є$ найслабшим і задає певну нижню межу критеріїв ефективності.

Аналогічний погляд на проблему продемонстрував Г. Саймон. У статті «Про мету організації» він розвиває думку про те, що максимізуюча поведінка не $€$ визначальною для агентів, які діють всередині фірми. Саймон вказує на те, що мотиви кожного учасника організації можна розділити на дві групи: по-перше, стимули (inducements) - аспекти участі в організації, яких потребує учасник; по-друге, внески (contributions) - аспекти участі, які $€$ внеском до виробничої функції організації, але мають від'ємну корисність для індивіда. При цьому, участь у діяльності організації передбачає визнання індивідом певної організаційної ролі та відповідній їй величині внеску до спільної справи, яка обмежує можливості максимізуючої поведінки. Тому, замість максимально можливого прибутку, який призведе до руйнування організації, економічний агент погоджується на отримання певного достатнього прибутку [17].

Х. Демсец зазначає, що не варто, вивчаючи ефективність, порівнювати ефективність існуючих інституцій 3 певним ідеалом [7]. О. Вільямсон теж вказує на те, що економічний агент не володіє повною інформацією про усі доступні альтернативні варіанти використання ресурсів, тому припиняє пошук коли досягає певного прийнятного результату. Можна ввести поняття подібне до нормального прибутку, аналізуючи ефективність системи інституцій [4]. Для менш розвинених країн чи організацій це буде найкращий 3 можливих рівнів трансакційних витрат.

C. Apхієрєєв та Я. Зінченко визначають показник ефективності інституції як співвідношення кількості трансакцій, які виконуються за допомогою інституції та загальної кількості трансакцій. Хоча 
зазначають при цьому, що даний показник не $\epsilon$ показником економічної ефективності, через те, що у ньому не співставляються витрати та вигоди від функціонування інституцій. Далі автори вказують на те, що показник економічної ефективності інституції повинен дорівнювати співвідношенню між економією на витратах товарних трансакцій та витрати інституціональних трансакцій [8, с. 60].

Ефективність торгової трансакції можна оцінювати як співвідношення витрат на обмін титулами власності та можливих вигод від обміну. Якщо відома реальна вартість (ринкова ціна за умов вільної конкуренції) предмету угоди то в якості критерію ефективності інституцій які забезпечують обмін можна використовувати відхилення ціни угоди від ринкової ціни [18].

Експерименти В. Сміта дають підстави стверджувати, що чим вищим $є$ коефіцієнт ефективності застосування агресії у розподільчому конфлікті, тим меншою є мотивація економічних агентів спрямовувати ресурси на економічне зростання. Можна також передбачити, що у повторюваному розподільчому конфлікті за умов зростаючої віддачі від масштабу застосування агресії, відбуватиметься боротьба за знищення конкурентів і, таким чином, це призведе до знищення інституцій, через те, що за умови, що контрагент лише один, вони стануть не потрібні [18].

Тверскі та Шафір провели експеримент, суть якого полягає у тому, що учаснику експерименту пропонували список виграшів, а потім давали дві картки з сумами виграшів та пропонували вибрати одну з них або за певну суму отримати третю картку та вибирати вже 3 трьох. Результати експерименту засвідчили цікаву особливість: якщо суми виграшів на перших двох картках були подібними то вимагалась третя картка, якщо ж одна з сум суттєво перевищувала іншу третю картку не вимагали [19].

Можна стверджувати, що реальна процедура вибору інституційної структури, інституційного дизайну подібна до цього експерименту за виключенням того, що інституційному підприємцю звичайно невідомі усі можливі виграші та він має можливість витрачати кошти на отримання інформації декілька разів.

Інституційний підприємець спочатку має інформацію про існуючи ділові практики чи інституції. Якщо одна з них дозволяє суттєво поліпшити ефективність - зекономити на трансакційних витратах підприємець не схильний витрачати ресурси на пошук та вивчення інших альтернатив. Тобто передумовою для інституційного пошуку $\epsilon$ однакова вигідність існуючих інституційних альтернатив. Звідси виходить, що трансакційні витрати пошуку інституційних альтернатив зростатимуть в умовах досконалої конкуренції.

Можна також передбачити зростання трансакційних витрат під час технологічних проривів, через те, що підтримання високих темпів розвитку технології вимагає високої концентрації ресурсів при впровадженні технології.

Також варто зазначити роль інституцій у регулюванні поведінки економічних агентів. У роботах Р. Талера та Д. Аріелі можна знайти багато прикладів, які ставлять під сумнів постулат неокласичної теорії про раціональну поведінку. Наприклад, Р. Талер аналізує такі прояви нераціональної поведінки, як трансакційну корисність, тобто суб'єктивну якість угоди, інакше кажучи, різницю між наявною та звичайною ціною, витратність самоконтролю, нестабільність споживчих переваг при міжчасовому виборі. Д. Аріелі вказує на 
відхилення поведінки від раціональної за умови емоційного перевантаження, аномально високої або низької ціни або наявності певних упереджень споживачів.

Отже, можна розглядати ефективність інституцій у контексті їхньої здатності до наближення поведінки людей до поведінки досконало раціональних економічних агентів.

На основі викладеного вище можна зробити кілька висновків. Критерії ефективності інституцій в економічній теорії не $є$ чітко визначеними. Ефективність з точки зору неокласиків полягає у тому, що ресурси використовуються ефективно, коли вони знаходяться у користуванні того, для кого вони представляють найвищу цінність, при чому остання визначається здатністю та готовністю сплатити за ресурс. А. Алчіян вказує на виживання економічного агента в умовах невизначеності як на критерій ефективності. Г. Саймон, досліджуючи організаційну поведінку вказує на те, що максимізуюча поведінка економічних агентів може бути визнана ефективною коли організація здатна існувати й далі. Розвиток інституцій сполучає у собі як елементи стихійної еволюції, так і осмисленого дизайну. Ефективна інституція 3 одного боку повинна приносити вигоду економічним агентам, при цьому зберігаючи їхню мотивацію відповідно до їхньої переговорної сили, а з іншого боку не повинна призводити до розмивання ресурсів, контрольованих однією з сторін.

Висновки та перспективи подальших досліджень. Підсумовуючи вище сказане, можна стверджувати, що ефективна інституція - це така інституція, яка забезпечує розподіл благ відповідно до переговорної сили економічних агентів та відносної цінності ресурсів, які залучено до контрактних відносин. Крім того, якщо існування інституції призводить до перерозподілу ресурсів на користь сильнішої сторони, $€$ небезпека того, що інституція виродиться, тобто усі ресурси будуть контролюватися лише однією з сторін і, у такий спосіб, мотивація до укладення угоди зникне. Вивчення різних підходів до визначення поняття інституційної ефективності дозволяє виявити суттєвий недолік існуючих оцінок ефективності інституцій, який полягає у нехтуванні нерівномірністю розподілу переговорної сили між економічними агентами. Ії урахування дозволяє визначити ефективну інституцію як таку, що забезпечує розподіл благ у відповідності до переговорної сили економічних агентів та відносної цінності ресурсів, які залучено до контрактних відносин. 3 огляду на це, у подальших дослідженнях доцільно приділити увагу особливостям оцінки переговорної сили в рамках застосування запропонованого критерію ефективності інститутів.

\section{Література:}

1. Норт Д. Інституції, інституційна зміна та функціонування економіки. Київ: Основи, 2000. 198 с.

2. Клишова Е.В. Методология исследования экономической рациональности. Наукові праці Донецького національного технічного університету. Серія: економічна. 2004. Випуск 70. С. 75-83.

3. Уильямсон О. Экономические институты капитализма: фирмы, рынки, «отношенческая» контрактация. СПб: Лениздат; CEV Press, 1996. 702 c.

4. Williamson $O$. Markets and Hierarchies: Analysis and Antitrust Implications. Free Press: New York, 1975. 286 p. 
5. Coase R. The Problem of Social Costs. Journal of Law and Economics. 1960. Vol. 3. P. 1-44.

6. Alchian A. Uncertainty, Evolution and Economic Theory. Journal of Political Economy. 1950. Vol. 58(3). P. 211-221.

7. Demsetz H. Toward Theory of Property Rights. American Economic Review. 1967. №57. P. 349-359.

8. Архиереев С. И., Зинченко Я. В. Трансакционные издержки институционализации фондового рынка. Харьков: ХНУ им. В.Н. Каразина, 2005. 248 с.

9. Дементьев В.В. Институты и поведение: социальный подход. Научные труды ДонНТУ. Серия: экономическая. 2005. Вып. 891. С. 5-19.

10. Alexander. E. R. Inter-organizational coordination and strategic planning: the architecture of institutional design, in Eds. W. Salet \& A. Faludi Inter-organizational coordination and strategic planning: the architecture of institutional design. (Royal Netherlands Academy of Arts and Sciences, Amsterdam). 2000. P. 159-174.

11. Buitelaar E. A theory of institutional change: Illustrated by Dutch city-provinces and Dutch land policy. Nijmengen. 2003. 44 p.

12. Ходжсон Дж. Экономическая теория и институты: Манифест современной институциональной экономической теории. М.: Дело, 2003. 435 с.

14. Шаститко А. Новая институциональная экономическая теория. М.: Экономический факультет МГУ, ТЕИС, 2002. 591 с.

15. Ellickson R. The Aim of Order Without Law. Journal of Institutional and Theoretical Economics. 1994. Vol.150(1). P. 97-100.

16. Miller J. Game Theory at Work: How to Use Game Theory to Outthink and Outmaneuver Your Competition. McGraw-Hill. 2003. $306 \mathrm{p}$.

17. Simon H. On the Concept of Organizational Goal. Administrative Science Quarterly. 1964. Vol. 9, No. 1. P. 1-22.

18. Durnharn Y., Hirshleifer J., Smith V. Do the Rich Get Richer and the Poor Poorer? Experimental Tests of Model of Power. The American Economic Review. 1998. Vol.88(4). P. 970-983.

19. Shafer G., Tversky A. Languages and Disigns for Probability Judgment. Cognitive Science. 1985. No. 9. P. 309-339.

20. Талер Р. Новая поведенческая экономика. Почему люди нарушают правила традиционной экономики и как на этом заработать. М.: Эксмо, 2017. 368 с.

21. Ариели Д. Поведенческая экономика. Почему люди ведут себя иррационально и как заработать на этом. М.: Манн, Иванов и Фербер, 2012. 296 c.

\section{References:}

1. Nort D. Instytuciji, instytucijna zmina ta funkcionuvannja ekonomiky. Kyjiv: Osnovy, 2000.198 s.

2. Klishova E. V. Metodologiya issledovaniya ekonomicheskoy ratsional'nosti. Naukovi pratsi Donets'kogo natsional'nogo tekhnichnogo universitetu. Seriya: ekonomichna. 2004. Vipusk 70. S. 75-83.

3. Uil'yamson O. Ekonomicheskie instituty kapitalizma: firmy, rynki, "otnoshencheskaya" kontraktatsiya. SPb: Lenizdat; CEV Press, 1996. 702 s.

4. Williamson $O$. Markets and Hierarchies: Analysis and Antitrust Implications. Free Press: New York, 1975. 286 p. 
5. Coase R. The Problem of Social Costs. Journal of Law and Economics. 1960. Vol. 3. P. 1-44.

6. Alchian A. Uncertainty, Evolution and Economic Theory. Journal of Political Economy. 1950. Vol. 58(3). P. 211-221.

7. Demsetz H. Toward Theory of Property Rights. American Economic Review. 1967. №57. P. 349-359.

8. Arkhiereev S. I., Zinchenko Ya. V. Transaktsionnye izderzhki institutsionalizatsii fondovogo rynka. Khar'kov: KhNU im. V.N. Karazina, 2005. $248 \mathrm{~s}$.

9. Dement'ev V. V. Instituty i povedenie: sotsial'nyy podkhod. Nauchnye trudy DonNTU. Seriya :ekonomicheskaya. 2005. Vyp. 89-1. S. 5-19.

10. Alexander. E. R. Inter-organizational coordination and strategic planning: the architecture of institutional design, in Eds. W. Salet \& A. Faludi Inter-organizational coordination and strategic planning: the architecture of institutional design. (Royal Netherlands Academy of Arts and Sciences, Amsterdam). 2000. P. 159-174.

11. Buitelaar E. A theory of institutional change: Illustrated by Dutch city-provinces and Dutch land policy. Nijmengen. 2003. 44 p.

12. Khodzhson Dzh. Ekonomicheskaya teoriya i instituty: Manifest sovremennoy institutsional'noy ekonomicheskoy teorii. M.: Delo, 2003. $435 \mathrm{~s}$.

14. Shastitko A. Novaya institutsional'naya ekonomicheskaya teoriya. M.: Ekonomicheskiy fakul'tet MGU, TEIS, 2002. $591 \mathrm{s.}$

15. Ellickson R. The Aim of Order Without Law. Journal of Institutional and Theoretical Economics. 1994. Vol.150(1). P. 97-100.

16. Miller J. Game Theory at Work: How to Use Game Theory to Outthink and Outmaneuver Your Competition. McGraw-Hill. 2003. $306 \mathrm{p}$.

17. Simon $H$. On the Concept of Organizational Goal. Administrative Science Quarterly. 1964. Vol. 9, No. 1. P. 1-22.

18. Durnharn Y., Hirshleifer J., Smith V. Do the Rich Get Richer and the Poor Poorer? Experimental Tests of Model of Power. The American Economic Review. 1998. Vol.88(4). P. 970-983.

19. Shafer G., Tversky A. Languages and Disigns for Probability Judgment. Cognitive Science. 1985. No. 9. P. 309-339.

20. Taler R. Novaya povedencheskaya ekonomika. Pochemu lyudi narushayut pravila traditsionnoy ekonomiki i kak na etom zarabotat'. M.: Eksmo, 2017. $368 \mathrm{~s}$.

21. Arieli D. Povedencheskaya ekonomika. Pochemu lyudi vedut sebya irratsional'no i kak zarabotat' na etom. M.: Mann, Ivanov i Ferber, 2012. 296 s.

The article proves that the concept of economic efficiency of institutions is currently unclear.

In this context, four approaches to the emergence and development of institutions are identified. The first approach is institutional design, which treats institutions as relationships that are created consciously. The second approach is the opposite of the first approach, which is called evolutionary. The third approach is proposed by $D$. North, which essence is that some institutions arise through the conscious activity of economic agents, others arise through evolution, 
but the choice of institutions in the past cuts off some of the possibilities of forming institutional configurations. The fourth approach is sociological, which assumes that institutions are formed and changed under the influence not so much of individual rationality and personal goals, but of group rationality and collective values. So, institutions are created in accordance with certain social standards. The formation and development of institutions leads to the formation of values that approve and confirm the functioning of institutions and, thus, the process becomes self-reinforcing.

It is argued that the process of institutionalization is currently influenced by pre-established institutional structures. Thus, in the process of institutional development, institutions become both a subject to be explained and an instrument of explanation, which usually complicates the analysis. In view of this, it is proven that institutional design and institutional evolution are not mutually exclusive alternatives.

The study of different approaches to the definition of institutional efficiency reveals a significant shortcoming of existing assessments of the effectiveness of institutions, which is to ignore the uneven distribution of bargaining power between economic agents. Its consideration allows to define an effective institution as one that ensures the distribution of benefits in accordance with the bargaining power of economic agents and the relative value of resources involved in the contractual relationship.

УДК 331.1

DOI: 10.35340/2308-104X.2021.90-1-02

ПРЕДИКТИВНА НR-АНАЛІТИКА

ЯК ІНСТРУМЕНТ УПРАВЛІННЯ

ЕФЕКТИВНІСТЮ ПЕРСОНАЛУ В

УМОВАХ ВІДДАЛЕНОГО

РОБОЧОГО СЕРЕДОВИЩА

БАЛУЄВА О. В., доктор економічних наук, професор, проректор з наукової роботи, CНОПЕНКО Г. В., аспірант, Донецький державний університет управління
PREDICTIVE HR-ANALYSIS AS A TOOL FOR PERSONNEL EFFICIENCY MANAGEMENT IN A REMOTE WORKING ENVIRONMENT

BALUEVA O., Doctor of Science in Economics, Full Professor, Vice-Rector for Research, SNOPENKO H., Post-graduate Student, Donetsk State University of Management

У статті доведено доцільність використання предиктивної HRаналітики 3 метою визначення неформальних лідерів і підвищення ефективності роботи віддалених команд. Запропоновано використання на підприємствах методу побудови ефективних команд на прикладі матриці лідерства, обгрунтовано його переваги. Визначено чинники, 